\title{
Hyperinsulinemia correlates with low levels of plasma B-type natriuretic peptide in Japanese men irrespective of fat distribution
}

\author{
Hideaki Nakatsuji ${ }^{1}$, Ken Kishida ${ }^{1,24^{*}}$, Tohru Funahashi ${ }^{1,2}$, Tohru Nakagawa ${ }^{3}$ and lichiro Shimomura ${ }^{1}$
}

\begin{abstract}
Background: B-type natriuretic peptide (BNP), a member of the natriuretic peptide family, is a cardiac-derived secretory hormone with natriuretic, diuretic, and vasorelaxant activities. Intraabdominal fat accumulation is associated with atherosclerotic cardiovascular diseases and cardiac dysfunction. Circulating BNP levels are relatively low (within the normal limits) in obesity and the metabolic syndrome. However, the relationship between plasma BNP levels and visceral fat accumulation in general population has not been reported. The present study analyzed the relationships between plasma BNP levels and various clinical variables, including insulin, visceral and subcutaneous fat area (VFA and SFA, respectively), in normal Japanese men.
\end{abstract}

Methods: The study (Victor-J study) subjects were consecutive 500 Japanese male workers, who underwent a health checkup and were measured VFA and SFA by computed tomography.

Results: Age-adjusted simple linear regression analysis showed that log-BNP correlated positively with HDLcholesterol, and negatively with VFA, log-immunoreactive insulin (IRI), log-triglyceride, and LDL-cholesterol, but not body mass index or SFA. Stepwise multiple regression analysis identified log-IRI and HDL-cholesterol as significant determinants of log-BNP. Subjects with $\mid R I \geq 5.5 \mu \mathrm{lU} / \mathrm{mL}$ had lower plasma BNP levels than those with $\mid \mathrm{RI}<5.5 \mu \mathrm{IU} /$ $\mathrm{mL}$, irrespective of obesity (body mass index, cutoff value $25 \mathrm{~kg} / \mathrm{m}^{2}$ ), visceral fat accumulation (VFA, cutoff value $100 \mathrm{~cm}^{2}$ ) and subcutaneous fat accumulation (SFA, cutoff value $128 \mathrm{~cm}^{2}$ ).

Conclusions: Our study showed that hyperinsulinemia correlated with low levels of plasma BNP in general men, irrespective of fat distribution.

Trial registration: UMIN 000004318 .

Keywords: B-type natriuretic peptide, Hyperinsulinemia, Visceral fat

\section{Background}

B-type natriuretic peptide (BNP), a member of the natriuretic peptide (NP) family, is a cardiac-derived secretory hormone with natriuretic, diuretic, and vasorelaxant activities [1,2]. Plasma BNP level correlates with the severity of heart failure, and is clinically used as a marker of cardiac dysfunction [3]. Evidence suggests that high BNP levels regulate endogenous antagonism of vasoconstriction, the salt- and water-retaining system that acts to prevent a rise in blood pressure, and plasma

\footnotetext{
* Correspondence: kkishida@imed2.med.osaka-u.ac.jp

'Department of Metabolic Medicine, Graduate School of Medicine, Osaka University, Suita, Osaka 565-0871, Japan

Full list of author information is available at the end of the article
}

volume expansion through direct natriuresis, diuresis, and vasodilation.

Visceral fat accumulation correlated closely with systolic blood pressure [4], and is also related to the development of cardiac dysfunction [5]. However, circulating NPs levels are relatively low (within the normal limits) in obesity [6-11]. It has been suggested that obese subjects have a "natriuretic handicap", with a reduced NPs response to cardiac wall stress. Low NPs levels may contribute to the pathophysiology of cardiac dysfunction in visceral adiposity. The present study analyzed the relationships between plasma BNP levels and various clinical variables, including insulin, visceral and subcutaneous fat

\section{C) Biomed Central}


area (VFA and SFA, respectively), in normal Japanese men.

\section{Methods \\ Participants}

The study subjects were consecutive 500 Japanese male employees, who underwent a health checkup in year 2010 at Hitachi Ltd, Ibaraki Prefecture, including computed tomography $(\mathrm{CT})$. The present study was approved by the human ethics committees of the National Center for Global Health and Medicine, Osaka University and Hitachi Health Care Center. Written informed consent was obtained from all subjects. This trial (Victor-J study) is registered with the University Hospital Medical Information Network (\#UMIN 000004318)

https://upload.umin.ac.jp/cgi-openbin/ctr/ctr.cgi?function $=$ brows \&action $=$ brows \& type $=$ summary\& recpt no $=$ R000005173\&lang uage $=E$.

\section{Anthropometry and laboratory measurements}

Height and weight were measured in standing position. Body mass index (BMI) was calculated and expressed in $\mathrm{kg} / \mathrm{m}^{2}$. Blood pressure was measured in a sitting position with a standard mercury sphygmomanometer on the right or left arm after the subjects had rested for at least 5 minutes. VFA and SFA were computed and measured automatically using commercial software on a CT scan taken at the umbilical level in supine position [120 $\mathrm{kV}, 400 \mathrm{mAsec}$, section thickness of 5-10 mm, field of view of $400 \mathrm{~mm}$, window width of 800-1,000 Hounsfield units]. Venous blood samples were collected in the morning after overnight fast for measurements of creatinine, hemoglobin A1c (HbA1c), HDL-cholesterol, LDLcholesterol, triglyceride, glucose, and immunoreactive insulin (IRI). The value for HbA1c (\%) is estimated as National Glycohemoglobin Standardization Program (NGSP) equivalent value (\%) calculated by the formula HbA1c $(\%)=$ HbA1c (Japan Diabetes Society [JDS],\%) + $0.4 \%$. Plasma BNP concentrations were measured with specific immunoradiometric assay for human BNP (BNP kit, Shionogi, Osaka, Japan, normal range; < 18.4 pg/mL, intracoefficients of variation $(\mathrm{CV}) ; 2.7-9.6 \%$, inter-CV $5.6-11.8 \%$, range $[2.0-2,000 \mathrm{pg} / \mathrm{mL}])$.

\section{Statistical analysis}

Data are presented as mean \pm SD (Tables) or mean \pm SEM (Figure). Stepwise multiple regression analysis was first conducted to identify those parameters that significantly contributed to log-BNP, and parameters with $F$ value $>4.0$ were subsequently entered into the regression analysis as independent variables. The subjects were divided into four groups according to; (analysis 1) BMI (cutoff value $25 \mathrm{~kg} / \mathrm{m}^{2}$; obesity) and IRI (cutoff value 5.5 $\mu \mathrm{IU} / \mathrm{mL}$; median value), (analysis 2) VFA (cutoff value $100 \mathrm{~cm}^{2}$; visceral fat accumulation) and IRI (cutoff value $5.5 \mu \mathrm{IU} / \mathrm{mL}$; median value), (analysis 3) SFA (cutoff value $128 \mathrm{~cm}^{2}$; median value) and IRI (cutoff value $5.5 \mu \mathrm{IU} /$ $\mathrm{mL}$; median value). Differences among groups were compared by one- or two-way analysis of variance (ANOVA) with Fisher's protected least significant difference test for multiple-group analysis or unpaired Student's $t$-test for experiments involving only two groups. In all cases, $p$ values $<0.05$ were considered statistically significant. All analyses were performed with the JMP Statistical Discovery Software 8.0 (SAS Institute, Cary, NC).

\section{Results}

Characteristics of subjects enrolled in the present study The baseline characteristics of the subjects who underwent a health checkup are listed in Table 1 . Only $12.4 \%(n=62)$ were hyper-BNPemic (above the normal range; upper limit of normal range; $\geq 18.4 \mathrm{pg} / \mathrm{mL}$ ), and $70.2 \%$ of the subjects $(\mathrm{n}=351)$ had visceral fat accumulation (VFA $\left.\geq 100 \mathrm{~cm}^{2}\right)$.

\section{Correlation analysis between plasma BNP levels and measured parameters}

Table 2 lists the correlation coefficients for the relationship between BNP and various clinical parameters. Data

Table 1 Baseline characteristics of male subjects participating in the present study $(n=500)$

\begin{tabular}{|c|c|}
\hline & $\begin{array}{l}\text { mean } \pm \text { SD } \\
\text { [range or } n(\%)]\end{array}$ \\
\hline Age, years & $55 \pm 9(30-74)$ \\
\hline Body mass index $(\mathrm{BMI}), \mathrm{kg} / \mathrm{m}^{2}$ & $24.2 \pm 3.0(14.8-36.5)$ \\
\hline Visceral fat area (VFA), $\mathrm{cm}^{2}$ & $127 \pm 54(3-294)$ \\
\hline Subcutaneous fat area (SFA), $\mathrm{cm}^{2}$ & $136 \pm 56(5-361)$ \\
\hline Blood glucose, mg/dL & $110 \pm 18(78-284)$ \\
\hline Fasting immunoreactive insulin (IRI), $\mu \mathrm{UU} / \mathrm{mL}$ & $6.7 \pm 4.5(0.6-42.3)$ \\
\hline HbA1c (NGSP), \% & $5.8 \pm 0.6(4.6-10.2)$ \\
\hline Systolic blood pressure (SBP), mmHg & $123 \pm 12(91-174)$ \\
\hline Diastolic blood pressure (DBP), mmHg & $78 \pm 8(47-100)$ \\
\hline Triglyceride, mg/dL & $140 \pm 95(35-871)$ \\
\hline $\begin{array}{l}\text { High-density lipoprotein cholesterol } \\
\text { (HDL-cholesterol), mg/dL }\end{array}$ & $56 \pm 13(32-97)$ \\
\hline $\begin{array}{l}\text { Low-density lipoprotein cholesterol } \\
\text { (LDL-cholesterol), mg/dL }\end{array}$ & $122 \pm 28(39-199)$ \\
\hline $\begin{array}{l}\text { Estimated glomerular filtration rate } \\
(\mathrm{eGFR}), \mathrm{mL} / \mathrm{min}\end{array}$ & $73.7 \pm 12.8(41.9-128.5)$ \\
\hline Plasma B-type natriuretic peptide (BNP), pg/mL & $10.8 \pm 13.0(2.0-159)$ \\
\hline Smoking (none/ex-/current-smoker) & $131 / 240 / 129$ \\
\hline Diabetes mellitus (under medication) & $24(17)$ \\
\hline Hypertension (under medication) & $116(115)$ \\
\hline Dyslipidemia (under medication) & $63(59)$ \\
\hline Past history of CAD/CVD & $5 / 3$ \\
\hline
\end{tabular}

CAD, coronary artery disease, CVD, Cerebrovascular disease Glomerular filtration rate was estimated by eGFR $=194 \times$ serum creatinine $1.094 \times$ age $^{-0.287}$ 
Table 2 Results of simple and stepwise multiple regression analyses for log-BNP

\begin{tabular}{llllll}
\hline & \multicolumn{2}{l}{$\begin{array}{l}\text { Simple (non- } \\
\text { adjusted) }\end{array}$} & \multicolumn{2}{l}{$\begin{array}{l}\text { Simple } \\
\text { (age-adjusted) }\end{array}$} & Multiple \\
\hline & $\boldsymbol{r}$ & $\boldsymbol{p}$ & $\boldsymbol{r}$ & $\boldsymbol{p}$ & $\boldsymbol{F}$ value \\
Age & 0.3688 & $<0.0001$ & - & - & \\
BMI & -0.1225 & 0.0069 & -0.0080 & 0.0559 & \\
VFA & -0.0707 & 0.1037 & -0.0010 & 0.0048 & 0.007 \\
SFA & -0.1342 & 0.0025 & -0.0004 & 0.0816 & \\
Blood glucose & 0.0837 & 0.0579 & 0.0003 & 0.7088 & \\
Log-IRl & -0.2408 & $<0.0001$ & -0.2430 & $<0.0001$ & 11.771 \\
HbA1C & 0.0894 & 0.0527 & 0.0050 & 0.8280 & \\
Systolic blood pressure & 0.1304 & 0.0031 & 0.0010 & 0.2595 & \\
Diastolic blood & -0.0134 & 0.7650 & 0.0020 & 0.2815 & \\
pressure & & & & & \\
Log-triglyceride & -0.1517 & 0.0007 & -0.1480 & 0.0079 & 0.385 \\
HDL-cholesterol & 0.2098 & $<0.0001$ & 0.0040 & $<0.0001$ & 6.437 \\
LDL-cholesterol & -0.1414 & 0.0014 & -0.0010 & 0.0088 & 2.377 \\
eGFR & -0.1304 & 0.0035 & -0.0004 & 0.6988 & \\
Smoking (ex-+current-) & -0.0088 & 0.8442 & -0.0090 & 0.7565 & \\
\hline
\end{tabular}

Data of BNP, IRI and triglyceride levels showed skewed distribution, and therefore were log-transformed before analysis. Multiple; [adopted factors: age, VFA, log-IRI, log-triglyceride, HDL-cholesterol, LDL-cholesterol]

of BNP showed skewed distribution (Figure 1A), and therefore were log-transformed before analysis. Ageadjusted simple linear regression analysis showed that log-BNP correlated positively with HDL-cholesterol (Figure 1B), and negatively with VFA, log-IRI (Figure 1B), log-triglyceride, and LDL-cholesterol, but not BMI or SFA. Stepwise multiple regression analysis identified HDL-cholesterol and log-IRI as significant and independent determinants of log-BNP.

\section{Comparisons of clinical features including plasma BNP} levels according to obesity and fat distribution

Subjects with IRI $\geq 5.5 \mu \mathrm{IU} / \mathrm{mL}$ had lower plasma BNP levels than those with IRI $<5.5 \mu \mathrm{IU} / \mathrm{mL}$, irrespective of obesity (analysis 1, Table 3 ), visceral fat accumulation (analysis 2, Table 4), and subcutaneous fat accumulation (analysis 3, Table 5) (Figure 2). These results suggest that hyperinsulinemia correlates with low levels of plasma BNP, irrespective of fat distribution.

\section{Discussion}

Our cross-sectional study of Japanese male subjects demonstrated for the first time that hyperinsulinemia correlated with low levels of plasma BNP, irrespective of fat distribution. The present study also found that HDL-cholesterol was a significant determinant of log-BNP. Although Wang et al. demonstrated that reduced HDL-cholesterol was associated with lower plasma BNP levels by multivariable analysis [12], the mechanism remains unclear.

As the mechanisms, we should consider the effect of hyperinsulinemia on BNP production and catabolism. There is controversy on whether or not hyperinsulinemia directly suppresses BNP production $[13,14]$. NPs, through the activation of the biologically active membrane guanylate-cyclase-linked NPR-1 has a potent lipolytic effect in human adipocytes via a cGMP-dependent mechanism [15] and activation of hormone-sensitive lipases [16,17]. Metabolism of NPs is regulated by two degradative pathways; uptake by the clearance receptor, natriuretic peptide receptor-3 (NPR-3) and hydrolysis by NEP [18]. Our and the other groups previously demonstrated that, 1) NPR-1, NPR-2 and NPR-3 mRNAs are expressed in the adipose tissues, however mRNA level of NEP is relatively low [19], and 2) lower NPR-1 mRNA levels and higher NPR-3 mRNA levels in the adipose tissues of $o b / o b$ mice [19] or in the adipose tissues and muscle of diet-induced mice [20], models of hyperinsulinemia, compared to lean mice. Plasma NEP levels were higher in diet-induced mice and tissue NEP was increased in mesenteric fat in diet-induced mice, compared with normal-diet mice [21]. The effect of insulin on NEP has not been reported. Taken together, dysregulation of two degradative pathways under
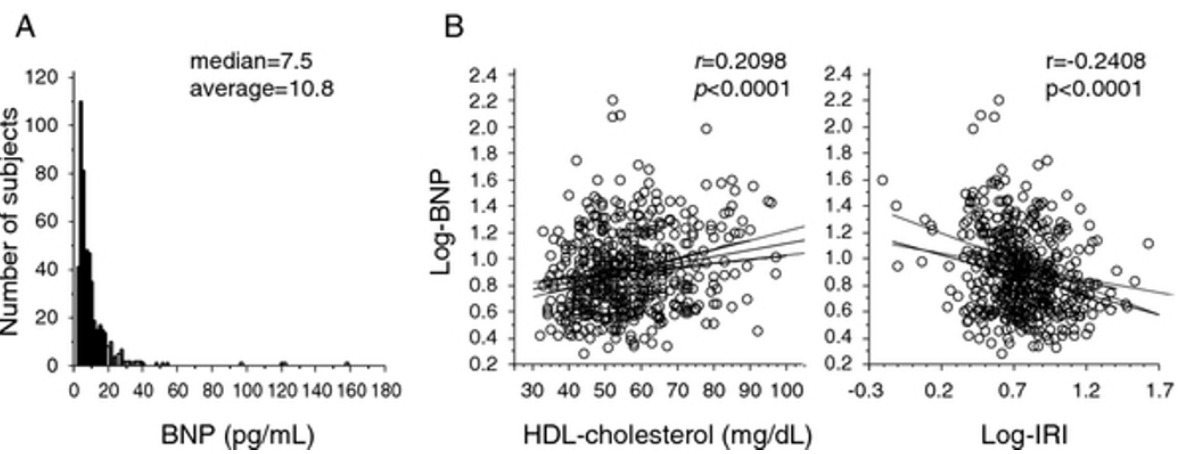

Figure 1 A histogram of plasma BNP levels and correlation between log-IRI, HDL-cholesterol and log-BNP. Pearson's correlation analysis was used to examine the relationships between log-IRI, HDL-cholesterol and log-BNP. Regression curve with 95\% confidence interval of predicted mean together with reference lines indicating baseline ( $0 \%$ change) 
Table 3 Comparison of clinical features between subjects without and with obesity (BMI cutoff value $25 \mathrm{~kg} / \mathrm{m}^{2}$ ) and hyperinsulinemia (IRI cutoff value $5.5 \mu \mathrm{IU} / \mathrm{mL}$; median value) (Analysis 1 ) $(\mathrm{n}=500$ )

\begin{tabular}{|c|c|c|c|c|}
\hline & $\mathrm{BMI}<25 \mathrm{~kg} / \mathrm{m}^{2}$ & & $\mathrm{BMI} \geq 25 \mathrm{~kg} / \mathrm{m}^{2}$ & \\
\hline & $\mathrm{IRI}<5.5 \mu \mathrm{IU} / \mathrm{mL}$ & $\mathrm{IRI} \geq 5.5 \mu \mathrm{lU} / \mathrm{mL}$ & $\mathrm{IRI}<5.5 \mu \mathrm{lU} / \mathrm{mL}$ & $\mathrm{IRI} \geq 5.5 \mu \mathrm{lU} / \mathrm{mL}$ \\
\hline Age, years & $55 \pm 9$ & $54 \pm 10$ & $55 \pm 8$ & $53 \pm 9$ \\
\hline $\mathrm{BMl}, \mathrm{kg} / \mathrm{m}^{2}$ & $22.1 \pm 1.8$ & $23.2 \pm 1.2^{*}$ & $26.2 \pm 1.5^{*}$ & $27.6 \pm 2.4^{\dagger \S}$ \\
\hline VFA, $\mathrm{cm}^{2}$ & $94 \pm 44$ & $131 \pm 40^{*}$ & $144 \pm 36^{*}$ & $171 \pm 45^{\dagger \S}$ \\
\hline SFA, $\mathrm{cm}^{2}$ & $103 \pm 36$ & $127 \pm 33^{*}$ & $154 \pm 42^{*}$ & $191 \pm 58^{\dagger \S}$ \\
\hline Blood glucose, mg/dL & $106 \pm 15$ & $114 \pm 20^{*}$ & $114 \pm 33^{*}$ & $111 \pm 13$ \\
\hline Fasting $\mid \mathrm{RI}, \mu \mathrm{I} \cup / \mathrm{mL}$ & $3.8 \pm 1.1$ & $7.8 \pm 2.6^{*}$ & $4.5 \pm 0.8^{*}$ & $11.0 \pm 5.8^{\dagger \S}$ \\
\hline $\mathrm{HbA1c}(\mathrm{NGSP}), \%$ & $5.7 \pm 0.5$ & $5.8 \pm 0.7^{*}$ & $6.0 \pm 0.9^{*}$ & $5.8 \pm 0.5$ \\
\hline $\mathrm{SBP}, \mathrm{mmHg}$ & $120 \pm 12$ & $124 \pm 11^{*}$ & $126 \pm 11^{*}$ & $125 \pm 10$ \\
\hline $\mathrm{DBP}, \mathrm{mmHg}$ & $76 \pm 8$ & $79 \pm 7^{*}$ & $78 \pm 14$ & $80 \pm 7$ \\
\hline Triglyceride, mg/dL & $117 \pm 88$ & $148 \pm 99^{*}$ & $171 \pm 112^{*}$ & $161 \pm 89$ \\
\hline HDL-cholesterol, mg/dL & $61 \pm 13$ & $55 \pm 12^{*}$ & $54 \pm 8^{*}$ & $51 \pm 11^{\dagger}$ \\
\hline LDL-cholesterol, mg/dL & $117 \pm 28$ & $121 \pm 27$ & $124 \pm 30$ & $131 \pm 27^{\dagger}$ \\
\hline $\mathrm{eGFR}, \mathrm{mL} / \mathrm{min}$ & $74 \pm 13$ & $76 \pm 13$ & $74 \pm 11$ & $71 \pm 13^{+}$ \\
\hline
\end{tabular}

Data are mean \pm SD

${ }^{*} \mathrm{p}<0.01$, compared to with $\mathrm{BMI}<25 \mathrm{~kg} / \mathrm{m}^{2}$ and $\mathrm{IRI}<5.5 \mu \mathrm{IU} / \mathrm{mL}$

${ }^{+} \mathrm{p}<0.01$, compared to with $\mathrm{BMI}<25 \mathrm{~kg} / \mathrm{m}^{2}$ and IRI $\geq 5.5 \mu \mathrm{IU} / \mathrm{mL}$

${ }_{\mathrm{s}} \mathrm{p}<0.01$ compared to with $\mathrm{BMI} \geq 25 \mathrm{~kg} / \mathrm{m}^{2}$ and $\mathrm{IRI}<5.5 \mu \mathrm{IU} / \mathrm{mL}$

hyperinsulinemia may be, at least partly, responsible for low circulating BNP levels.

Amino-terminal pro-BNP (NT-proBNP), which is cosecreted in equimolar amounts with BNP from the cardiac ventricle, is also well-established as a diagnostic marker in heart failure [22,23]. Surgical weight loss with reduced insulin levels was associated with increases in NT-proBNP [24]. Women with gestational diabetes mellitus under insulin therapy had lower circulating NTproBNP levels than those under medical nutrition therapy or healthy pregnancies [25]. These results suggest that circulating levels of NT-proBNP as well as BNP may be regulated by insulin. However, clearance of plasma NT-proBNP occurred across kidney, liver, musculoskeletal, and head and neck tissue [26], differ from plasma BNP cleared by NPRs and NEP. Further experimental and clinical studies including both BNP and NTproBNP are required. Improvement of hyperinsulinemia may reduce plasma volume and thus lower blood pressure through the increase in plasma NPs levels. This

Table 4 Comparison of clinical features between subjects without and with visceral fat accumulation (VFA cutoff value $100 \mathrm{~cm}^{2}$ ) and hyperinsulinemia (IRI cutoff value $5.5 \mu \mathrm{IU} / \mathrm{mL}$; median value) (Analysis 2) (n = 500)

\begin{tabular}{|c|c|c|c|c|}
\hline & VFA $<100 \mathrm{~cm}^{2}$ & & VFA $\geq 100 \mathrm{~cm}^{2}$ & \\
\hline & $\mathrm{IRI}<5.5 \mu \mathrm{IU} / \mathrm{mL}$ & $\mathrm{IRI} \geq 5.5 \mu \mathrm{IU} / \mathrm{mL}$ & $\mathrm{IRI}<5.5 \mu \mathrm{IU} / \mathrm{mL}$ & $\mathrm{IRI} \geq 5.5 \mu \mathrm{IU} / \mathrm{mL}$ \\
\hline Age, years & $53 \pm 11$ & $47 \pm 12^{*}$ & $56 \pm 8^{*}$ & $54 \pm 9^{\dagger \S}$ \\
\hline $\mathrm{BMI}, \mathrm{kg} / \mathrm{m}^{2}$ & $21.6 \pm 2.0$ & $23.1 \pm 2.5^{*}$ & $23.9 \pm 2.0^{*}$ & $25.9 \pm 2.8^{+\S}$ \\
\hline VFA, $\mathrm{cm}^{2}$ & $63 \pm 26$ & $72 \pm 24$ & $139 \pm 28^{*}$ & $162 \pm 40^{\dagger \S}$ \\
\hline SFA, $\mathrm{cm}^{2}$ & $92 \pm 38$ & $114 \pm 58^{*}$ & $129 \pm 37^{*}$ & $167 \pm 55^{\dagger \S}$ \\
\hline Blood glucose, mg/dL & $104 \pm 14$ & $110 \pm 14$ & $110 \pm 23^{*}$ & $113 \pm 17$ \\
\hline Fasting $\mid \mathrm{RI}, \mu \mathrm{IU} / \mathrm{mL}$ & $3.6 \pm 1.1$ & $7.1 \pm 1.4^{*}$ & $4.2 \pm 0.9^{*}$ & $9.8 \pm 5.0^{\dagger \S}$ \\
\hline $\mathrm{HbA1c}(\mathrm{NGSP}), \%$ & $5.6 \pm 0.5$ & $5.6 \pm 0.5$ & $5.8 \pm 0.6^{*}$ & $5.9 \pm 0.6$ \\
\hline $\mathrm{SBP}, \mathrm{mmHg}$ & $118 \pm 12$ & $121 \pm 13$ & $123 \pm 11^{*}$ & $125 \pm 10$ \\
\hline $\mathrm{DBP}, \mathrm{mmHg}$ & $75 \pm 9$ & $77 \pm 7$ & $78 \pm 10^{*}$ & $80 \pm 7^{\S}$ \\
\hline Triglyceride, mg/dL & $101 \pm 63$ & $108 \pm 49$ & $149 \pm 111^{*}$ & $160 \pm 96^{\dagger}$ \\
\hline HDL-cholesterol, mg/dL & $62 \pm 13$ & $57 \pm 10$ & $58 \pm 13^{*}$ & $52 \pm 12^{\dagger \S}$ \\
\hline LDL-cholesterol, mg/dL & $115 \pm 29$ & $124 \pm 25$ & $121 \pm 28$ & $127 \pm 28$ \\
\hline $\mathrm{eGFR}, \mathrm{mL} / \mathrm{min}$ & $76 \pm 12$ & $79 \pm 13$ & $73 \pm 12$ & $73 \pm 13^{+}$ \\
\hline
\end{tabular}

Data are mean \pm SD

${ }^{*} \mathrm{p}<0.01$, compared to with VFA $<100 \mathrm{~cm}^{2}$ and IRI $<5.5 \mu \mathrm{IU} / \mathrm{mL}$ ${ }^{+} \mathrm{p}<0.01$, compared to with VFA $<100 \mathrm{~cm}^{2}$ and IRI $\geq 5.5 \mu \mathrm{IU} / \mathrm{mL}$ ${ }^{\S} \mathrm{p}<0.01$ compared to with VFA $\geq 100 \mathrm{~cm}^{2}$ and $\mathrm{IRI}<5.5 \mu \mathrm{IU} / \mathrm{mL}$ 
Table 5 Comparison of clinical features between subjects without and with subcutaneous fat accumulation (SFA cutoff value $128 \mathrm{~cm}^{2}$; median value) and hyperinsulinemia (IRI cutoff value $5.5 \mu \mathrm{IU} / \mathrm{mL}$; median value) (Analysis 3 ) (n = 500)

\begin{tabular}{|c|c|c|c|c|}
\hline & SFA $<128 \mathrm{~cm}^{2}$ & & SFA $\geq 128 \mathrm{~cm}^{2}$ & \\
\hline & $\mathrm{IRI}<5.5 \mu \mathrm{IU} / \mathrm{mL}$ & $\mathrm{IRI} \geq 5.5 \mu \mathrm{lU} / \mathrm{mL}$ & $\mathrm{IRI}<5.5 \mu \mathrm{IU} / \mathrm{mL}$ & $\mathrm{IRI} \geq 5.5 \mu \mathrm{lU} / \mathrm{mL}$ \\
\hline Age, years & $55 \pm 9$ & $55 \pm 10$ & $55 \pm 9$ & $52 \pm 9^{+}$ \\
\hline $\mathrm{BMI}, \mathrm{kg} / \mathrm{m}^{2}$ & $21.9 \pm 1.9$ & $23.4 \pm 1.9^{*}$ & $24.7 \pm 1.9^{*}$ & $26.6 \pm 2.8^{\dagger \S}$ \\
\hline VFA, $\mathrm{cm}^{2}$ & $88 \pm 43$ & $128 \pm 48^{*}$ & $131 \pm 41^{*}$ & $164 \pm 43^{\dagger \S}$ \\
\hline SFA, $\mathrm{cm}^{2}$ & $91 \pm 27$ & $104 \pm 21^{*}$ & $157 \pm 31^{*}$ & $187 \pm 50^{\dagger \S}$ \\
\hline Blood glucose, mg/dL & $106 \pm 20$ & $115 \pm 19^{*}$ & $108 \pm 16$ & $111 \pm 16$ \\
\hline Fasting $\mid \mathrm{RI}, \mu \mathrm{IU} / \mathrm{mL}$ & $3.7 \pm 1.1$ & $7.4 \pm 1.9^{*}$ & $4.4 \pm 0.9^{*}$ & $10.4 \pm 5.4^{\dagger \S}$ \\
\hline $\mathrm{HbA} 1 \mathrm{c}(\mathrm{NGSP}), \%$ & $5.7 \pm 0.5$ & $5.9 \pm 0.7^{*}$ & $5.8 \pm 0.6$ & $5.8 \pm 0.5$ \\
\hline $\mathrm{SBP}, \mathrm{mmHg}$ & $120 \pm 13$ & $126 \pm 13^{*}$ & $123 \pm 11^{*}$ & $124 \pm 10$ \\
\hline $\mathrm{DBP}, \mathrm{mmHg}$ & $76 \pm 8$ & $79 \pm 7^{*}$ & $78 \pm 11$ & $80 \pm 7$ \\
\hline Triglyceride, mg/dL & $117 \pm 81$ & $157 \pm 114^{*}$ & $145 \pm 117^{*}$ & $153 \pm 83$ \\
\hline HDL-cholesterol, mg/dL & $62 \pm 13$ & $55 \pm 11^{*}$ & $56 \pm 12^{*}$ & $51 \pm 12^{\dagger \S}$ \\
\hline LDL-cholesterol, mg/dL & $119 \pm 31$ & $124 \pm 30$ & $118 \pm 24$ & $128 \pm 26^{\S}$ \\
\hline $\mathrm{eGFR}, \mathrm{mL} / \mathrm{min}$ & $75 \pm 13$ & $74 \pm 15$ & $73 \pm 11$ & $73 \pm 12$ \\
\hline
\end{tabular}

Data are mean \pm SD

${ }^{*} \mathrm{p}<0.01$, compared to with SFA $<128 \mathrm{~cm}^{2}$ and $\mathrm{IRI}<5.5 \mu \mathrm{IU} / \mathrm{mL}$

${ }^{+} \mathrm{p}<0.01$, compared to with SFA $<128 \mathrm{~cm}^{2}$ and IRI $\geq 5.5 \mu \mathrm{IU} / \mathrm{mL}$

${ }^{\S} \mathrm{p}<0.01$ compared to with SFA $\geq 128 \mathrm{~cm}^{2}$ and $\mathrm{IRI}<5.5 \mu \mathrm{IU} / \mathrm{mL}$

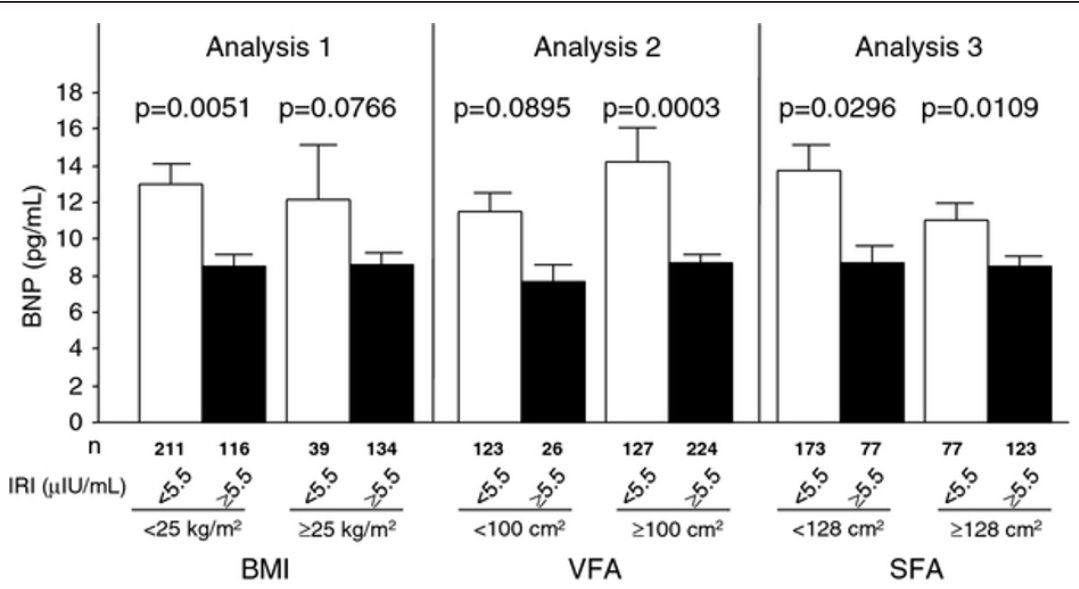

Figure 2 Comparison of plasma BNP levels between subjects without and with hyperinsulinemia (IRI cutoff value $5.5 \mu \mathrm{IU} / \mathrm{mL}$; median value), and obesity (BMI cutoff value $25 \mathrm{~kg} / \mathrm{m}^{2}$, Analysis 1), visceral fat accumulation (VFA cutoff value $100 \mathrm{~cm}^{2}$, Analysis 2 ) or subcutaneous fat accumulation (SFA cutoff value $128 \mathrm{~cm}^{2}$; median value, Analysis 3 ). Data are mean \pm SEM.

may reduce susceptibility for cardiac dysfunction in subjects with hyperinsulinemia.

\section{Conclusion}

In conclusion, hyperinsulinemia correlated with low levels of plasma BNP in general men, irrespective of fat distribution.

\section{Study limitations}

Several limitations of this study must be considered. First, this is a cross-sectional study, making it difficult to establish a cause-effect relationship. Further prospective studies should be conducted in the future to analyze this relationship. Second, the results may not be applicable to females or non-Japanese populations. Finally, in the present study, drug information was based on information provided by the subjects or their relatives. The current study may include the effects of use of various medications for diabetes, hypertension and dyslipidemia. Further studies that include untreated patients need to be conducted.

\section{Abbreviations}

BNP: B-type natriuretic peptide; CT: Computed tomography; IRI: Immunoreactive insulin; NEP: Neutral endopeptidase; NP: Natriuretic peptide; NPR: Natriuretic peptide receptor; SFA: Subcutaneous fat area; VFA: Visceral fat area. 


\section{Acknowledgements}

We thank all staff at Hitachi, Ltd. Hitachi Health Care Center for the data collection and technical assistance. This research was supported in part by a Grant-in-Aid for Scientific Research on Innovative Areas (Research in a proposed research area) "Molecular Basis and Disorders of Control of Appetite and Fat Accumulation" (\#22126008, to T.F. and K.K.).

\section{Author details}

'Department of Metabolic Medicine, Graduate School of Medicine, Osaka University, Suita, Osaka 565-0871, Japan. ${ }^{2}$ Department of Metabolism and Atherosclerosis, Graduate School of Medicine, Osaka University, Suita, Osaka 565-0871, Japan. ${ }^{3}$ Hitachi, Ltd. Hitachi Health Care Center, Hitachi, Ibaraki 317-0076, Japan. ${ }^{4}$ Department of Metabolism and Atherosclerosis, Graduate School of Medicine, Osaka University, 2-2 B-5, Yamada-oka, Suita, Osaka 5650871, Japan.

\section{Authors' contributions}

$\mathrm{HN}$ and KK researched and analyzed data. KK also participated in the concept and design of the study, interpretation of data and reviewed/edited the manuscript. TN recruited the patients and collected the data. TF and IS contributed to discussion and wrote the manuscript. All authors read and approved the final version of the manuscript.

\section{Competing interests}

K.K. and T.F. are members of the "Department of Metabolism and Atherosclerosis", a sponsored course endowed by Kowa Co. Ltd. and a company researcher is dispatched to the course. All other authors declare no competing interests.

Received: 19 January 2012 Accepted: 7 March 2012 Published: 7 March 2012

\section{References}

1. Mukoyama M, Nakao K, Hosoda K, Suga S, Saito Y, Ogawa Y, Shirakami G, Jougasaki M, Obata K, Yasue H, Kambayashi Y, Inoue K, Imura H: Brain natriuretic peptide as a novel cardiac hormone in humans. Evidence for an exquisite dual natriuretic peptide system, atrial natriuretic peptide and brain natriuretic peptide. J Clin Invest 1991, 87:1402-1412.

2. Levin ER, Gardner DG, Samson WK: Natriuretic peptides. N Engl J Med 1998, 339:321-328

3. Nakamura M, Endo H, Nasu M, Arakawa N, Segawa T, Hiramori K: Value of plasma $B$ type natriuretic peptide measurement for heart disease screening in a Japanese population. Heart 2002, 87:131-135.

4. Kanai H, Matsuzawa Y, Kotani K, Keno Y, Kobatake T, Nagai Y, Fujioka S, Tokunaga K, Tarui S: Close correlation of intra-abdominal fat accumulation to hypertension in obese women. Hypertension 1990, 16:484-490.

5. Nakajima T, Fujioka S, Tokunaga K, Matsuzawa Y, Tarui S: Correlation of intraabdominal fat accumulation and left ventricular performance in obesity. Am J Cardiol 1989, 64:369-373.

6. Sugisawa T, Kishimoto I, Kokubo Y, Makino H, Miyamoto Y, Yoshimasa Y: Association of plasma B-type natriuretic peptide levels with obesity in a general urban Japanese population: the Suita study. Endocr J 2010, 57:727-733.

7. Horwich $T B$, Hamilton MA, Fonarow GC: B-type natriuretic peptide levels in obese patients with advanced heart failure. J Am Coll Cardiol 2006, 47:85-90.

8. McCord J, Mundy BJ, Hudson MP, Maisel AS, Hollander JE, Abraham WT, Steg PG, Omland T, Knudsen CW, Sandberg KR, McCullough PA: Breathing not properly multinational study investigators: relationship between obesity and B-type natriuretic peptide levels. Arch Intern Med 2004, 164:2247-2252.

9. Wang TJ, Larson MG, Levy D, Benjamin EJ, Leip EP, Wilson PW, Vasan RS: Impact of obesity on plasma natriuretic peptide levels. Circulation 2004, 109:594-600

10. Khan AM, Cheng S, Magnusson M, Larson MG, Newton-Cheh C, McCabe EL, Coviello AD, Florez JC, Fox CS, Levy D, Robins SJ, Arora P, Bhasin S, Lam CS, Vasan RS, Melander O, Wang TJ: Cardiac natriuretic peptides, obesity, and insulin resistance: evidence from two community-based studies. J Clin Endocrinol Metab 2011, 96:3242-3249.
11. Cheng S, Fox CS, Larson MG, Massaro JM, McCabe EL, Khan AM, Levy D, Hoffmann U, O'Donnell CJ, Miller KK, Newton-Cheh C, Coviello AD, Bhasin S, Vasan RS, Wang TJ: Relation of visceral adiposity to circulating natriuretic peptides in ambulatory individuals. Am J Cardiol 2011, 108:979-984.

12. Wang TJ, Larson MG, Keyes MJ, Levy D, Benjamin EJ, Vasan RS: Association of plasma natriuretic peptide levels with metabolic risk factors in ambulatory individuals. Circulation 2007, 115:1345-1353.

13. Tanabe A, Naruse M, Wasada T, Naruse K, Yoshimoto T, Omori Y, Demura H: Effects of acute hyperinsulinemia on plasma atrial and brain natriuretic peptide concentrations. Eur J Endocrinol 1995, 132:693-698.

14. Halbirk M, Nørrelund H, Møller N, Schmitz O, Bøtker HE, Wiggers H: Shortterm changes in circulating insulin and free fatty acids affect Nt-pro-BNP levels in heart failure patients. Int J Cardiol 2010, 144:140-142.

15. Sengenes C, Bouloumie A, Hauner $H$, Berlan M, Busse R, Lafontan M, Galitzky J: Involvement of a cGMP-dependent pathway in the natriuretic peptide-mediated hormone-sensitive lipase phosphorylation in human adipocytes. J Biol Chem 2003, 278:48617-48626.

16. Birkenfeld AL, Boschmann M, Moro C, Adams F, Heusser K, Franke G, Berlan $M$, Luft FC, Lafontan $M$, Jordan J: Lipid mobilization with physiological atrial natriuretic peptide concentrations in humans. J Clin Endocrinol Metab 2005, 90:3622-3628.

17. Savoia C, Volpe M, Alonzo A, Rossi C, Rubattu S: Natriuretic peptides and cardiovascular damage in the metabolic syndrome: molecular mechanisms and clinical implications. Clin Sci (Lond) 2009, 118:231-240.

18. Kenny AJ, Bourne A, Ingram J: Hydrolysis of human and pig brain natriuretic peptides, urodilatin, C-type natriuretic peptide and some Creceptor ligands by endopeptidase-24.11. Biochem J 1993, 291:83-88.

19. Nakatsuji H, Maeda N, Hibuse T, Hiuge A, Hirata A, Kuroda Y, Kishida K, Kihara S, Funahashi T, Shimomura I: Reciprocal regulation of natriuretic peptide receptors by insulin in adipose cells. Biochem Biophys Res Commun 2010, 392:100-105.

20. Miyashita $\mathrm{K}$, Itoh $\mathrm{H}$, Tsujimoto $\mathrm{H}$, Tamura N, Fukunaga $\mathrm{Y}$, Sone $\mathrm{M}$, Yamahara K, Taura D, Inuzuka M, Sonoyama T, Nakao K: Natriuretic peptides/cGMP/cGMP -dependent protein kinase cascades promote muscle mitochondrial biogenesis and prevent obesity. Diabetes 2009, 58:2880-2892.

21. Standeven KF, Hess K, Carter AM, Rice GI, Cordell PA, Balmforth AJ, Lu B, Scott DJ, Turner AJ, Hooper NM, Grant PJ: Neprilysin, obesity and the metabolic syndrome. Int J Obes (Lond) 2011, 35:1031-1040.

22. McCullough PA, Nowak RM, McCord J, Hollander JE, Herrmann HC, Steg PG, Duc P, Westheim A, Omland T, Knudsen CW, Storrow AB, Abraham WT, Lamba S, Wu AH, Perez A, Clopton P, Krishnaswamy P, Kazanegra R, Maisel AS: B-type natriuretic peptide and clinical judgment in emergency diagnosis of heart failure: analysis from Breathing Not Properly (BNP) multinational study. Circulation 2002, 106:416-422.

23. Kim HN, Januzzi $J L \mathrm{Jr}$ : Natriuretic peptide testing in heart failure. Circulation 2011, 123:2015-2019.

24. Chen-Tournoux A, Khan AM, Baggish AL, Castro VM, Semigran MJ, McCabe EL, Moukarbel G, Reingold J, Durrani S, Lewis GD, Newton-Cheh C, Scherrer-Crosbie M, Kaplan LM, Wang TJ: Effect of weight loss after weight loss surgery on plasma $\mathrm{N}$-terminal pro-B-type natriuretic peptide levels. Am J Cardiol 2010, 106:1450-1455.

25. Andreas M, Zeisler $H$, Handisurya A, Franz MB, Gottsauner-Wolf M, Wolzt M, Kautzky-Willer A: N-terminal-pro-brain natriuretic peptide is decreased in insulin dependent gestational diabetes mellitus: a prospective cohort trial. Cardiovasc Diabetol 2011, 10:28.

26. Palmer SC, Yandle TG, Nicholls MG, Frampton CM, Richards AM: Regional clearance of amino-terminal pro-brain natriuretic peptide from human plasma. Eur J Heart Fail 2009, 11:832-839.

doi:10.1186/1475-2840-11-22

Cite this article as: Nakatsuji et al: Hyperinsulinemia correlates with low levels of plasma B-type natriuretic peptide in Japanese men irrespective of fat distribution. Cardiovascular Diabetology 2012 11:22. 